\title{
Simulations of Grid-Connected Photovoltaic System in Qena Al-Gadida City
}

\author{
Ibrahim A. Nassar ${ }^{1}$, Abdelrahman A. Z. Saleh ${ }^{2}$ \\ Lecturer, Electrical Power and Machine Department, Faculty of Engineering, Alazhar University, Cairo, Egypt ${ }^{1}$ \\ Electrical Engineer, New Urban Communities Authority, Qena, Egypt ${ }^{2}$
}

\begin{abstract}
This paper introduces grid-connected PV system to provide electricity for loads fractions of the governmental building in "Qena Al-Gadida" through two plans with different prices of electricity according to consumption rates. The first plan assuming the price of electricity purchased from the grid is equal to the price paid by the utility for electricity sold to the grid (sellback price). The second plan assumes that the sellback price is higher than the grid power price. HOMER package used for simulation.
\end{abstract}

Keywords: Photovoltaic, Modules, Inverter, NPC, COE, Grid, Sale, Sellback, Electricity, Simulation, Load, Consumption, Homer, Kwh, Prices, Connected, Temperature, Governmental, Buildings, City, Qena Al-Gadida, NUCA, Diesel.

\section{INTRODUCTION}

Egypt is endowed with natural resources and enormous potentials of renewable energy, especially solar, which encourages implementing renewable energy projects in the country. Applications of photovoltaic systems have been spread for lighting, water pumping, telecommunications, cooling and advertisement purposes on the commercial scale in Egypt [1]. This study introduces electricity supply of a percentage of loads for the governmental building in Qena Al-Gadida city to make reduction of loads on the grid., and make comparison between electricity cost (L.E/kWh) using PV panels and the local electricity supply, it aims to investigate at which extend on grid system is cost effective and to find the optimum solution of on grid PV systems that will be suitable to the building assuming PV fractions to supply loads $(0,25,50,75) \%$ [2-9].

\section{INPUT DATA}

HOMER can accept input data either directly through the user interface or through file import [10].

\section{A. The Load Profile}

The typical operating hours for most governmental buildings in Egypt is from 8:00am to 5:00pm for five days a week with two days off. During working hours, it was assumed that the building used the highest load with only a minimum load used during the evenings and the nights. The load was assumed to be $90 \%$ during operating hours and $10 \%$ during the evenings and nights in the winter seasons. During the summer season, the load was assumed to be $80 \%$ during the operating hours and $20 \%$ during the evenings and nights [11]. The annual peak load is $427 \mathrm{KW}$ with energy consumption of $2.6 \mathrm{MWh} /$ day and the daily profile of the load is shown in Figure (1).

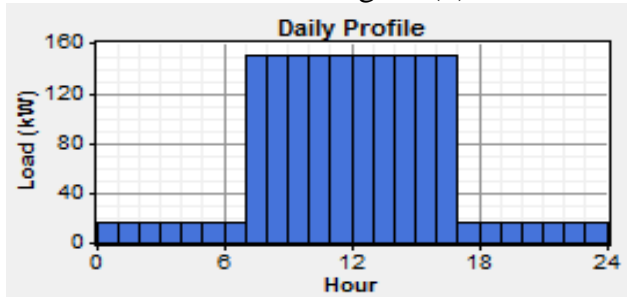

Figure (1): the load profile of Qena Al-Gadida

\section{B. The Temperature of the City}

When HOMER includes temperature effects in PV simulations, it requires the user to input the ambient temperature for the location of the panels as shown in figure (2).

Once again, HOMER gives the user the option of retrieving this data from, which provides an average ambient temperature for each month. The user also has the option to insert more precise data [12].

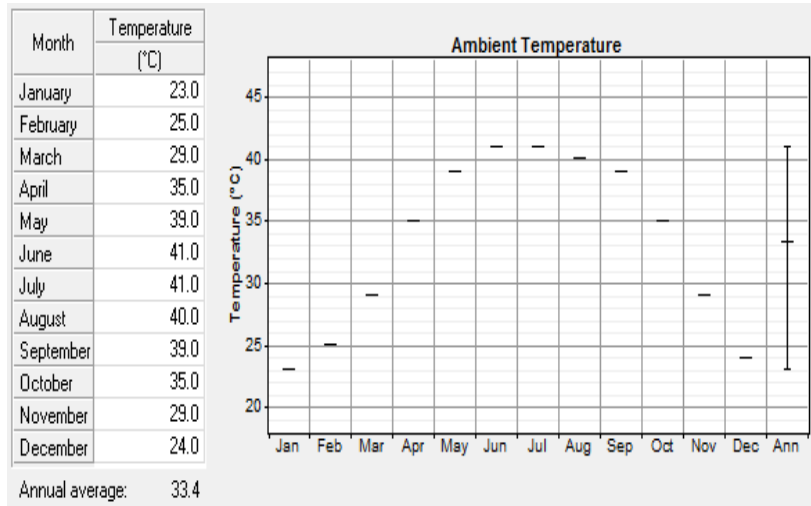

Figure (2): Temperature data of Qena Al-Gadida

\section{The Grid information}

The rate used is the current price of electricity in Egypt. The exact cost was used because the Egypt electricity company has different electricity prices depending on the sector, season, and time.

The Egypt price for the governmental buildings sector was obtained from the electricity utility [13] then converted to dollars and entered in to HOMER. For this study therefore two plans will be assumed.

In the first plan the sellback price will be equal to the price of the utility. Figure (3) shows the rate table for the Price used in the first plan. 
INTERNATIONAL JOURNAL OF INNOVATIVE RESEARCH IN ELECTRICAL, ELECTRONICS, INSTRUMENTATION AND CONTROL ENGINEERING Vol. 3, Issue 3, March 2015

\begin{tabular}{|c|c|c|c|}
\hline Rate & $\begin{array}{c}\text { Price } \\
(\$ / k W h)\end{array}$ & $\begin{array}{l}\text { Selllback } \\
\text { (\$/kWh) }\end{array}$ & $\begin{array}{l}\text { Demand } \\
(\$ / \mathrm{kW} / \mathrm{mo})\end{array}$ \\
\hline 0.32 L.E & 0.046 & 0.046 & 0.000 \\
\hline 0.50 L.E & 0.071 & 0.071 & 0.000 \\
\hline 0.61 L.E & 0.087 & 0.087 & 0.000 \\
\hline Add & Remove & & Edit... \\
\hline
\end{tabular}

In the second plan, the sellback price is assumed to be the highest price. The reason for this assumption is that the PV system will be providing power during peak hours; therefore, it is fair to assume a peak hour price. Figure (4) shows the rate table for the second plan.

\begin{tabular}{|c|c|c|c|}
\hline Rate & $\begin{array}{c}\text { Price } \\
(\$ / \mathrm{kWh})\end{array}$ & $\begin{array}{l}\text { Selllback } \\
\text { (\$/kWh) }\end{array}$ & $\begin{array}{c}\text { Demand } \\
(\$ / \mathrm{kW} / \mathrm{mo})\end{array}$ \\
\hline $\begin{array}{l}0.32 \text { L.E } \\
0.50 \text { L.E } \\
0.61 \text { L.E }\end{array}$ & $\begin{array}{l}0.046 \\
0.071 \\
0.087\end{array}$ & $\begin{array}{l}0.130 \\
0.130 \\
0.130\end{array}$ & $\begin{array}{l}0.000 \\
0.000 \\
0.000\end{array}$ \\
\hline Add & Remove & & Edit... \\
\hline
\end{tabular}

\section{Solar resource}

The annual average insolation level at Qena Al-Gadida is $5.89 \mathrm{kWh} / \mathrm{m} 2 /$ day, the monthly clearness index and the daily radiation are shown in Figure (5) [14].

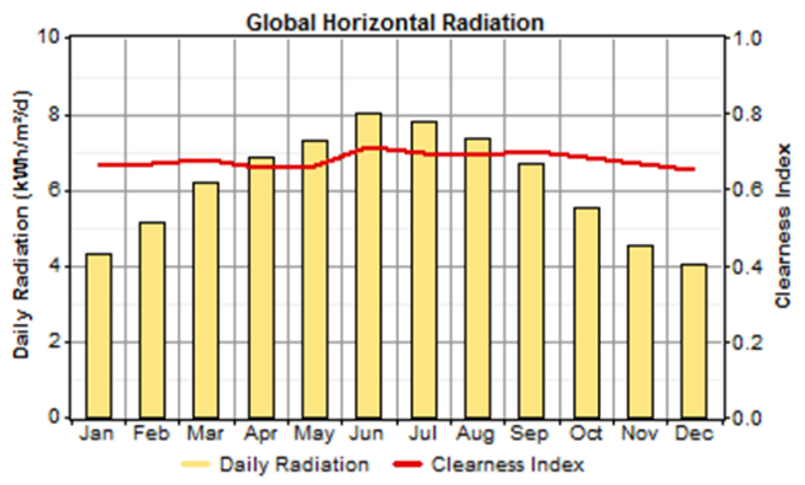

Figure (5): Qena Al-Gadida solar irradiance

\section{E. Economic Entries}

The most important economic factors for HOMER are the real interest rate and the project lifetime. For the real interest rate (discount rate) in Egypt $2 \%$ was added. The normal project lifetime for any PV system is between 25-30 years. A 25-year lifetime was chosen and was added to HOMER Figure (6).

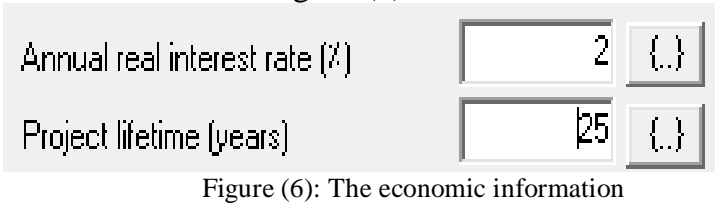

\section{F. Constraints}

Figure (6): The economic information

HOMER was forced to follow the assumption that chose the fraction covered by the PV System. The fraction chosen is shown in Figure (7).

Copyright to IJIREEICE

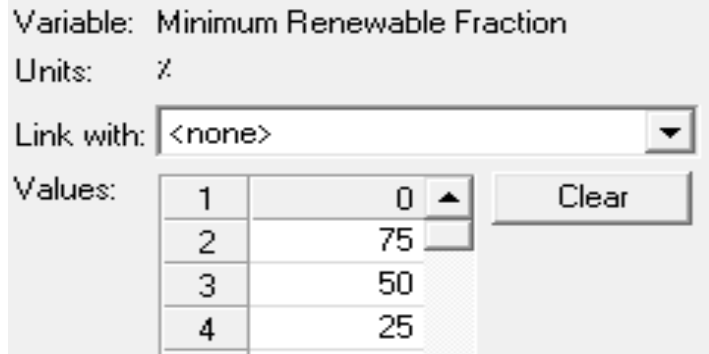

Figure (7): The fraction covered by PV system

All data was entered into HOMER for simulation. Figure (8) shows the final system configuration after all the data needed for the simulation was entered.

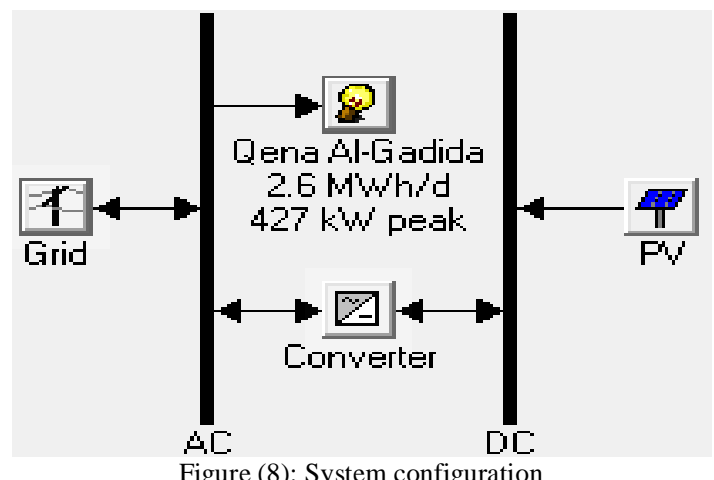

III.SIMULATIONS

Figure (9) shows that increase in diesel price has a significant effect on the NPC by choosing to supply the load by a hybrid system (PV and diesel). From a base price of $\$ 0.25 / \mathrm{L}$ when the NPC is $\$ 107,255$, the NPC increases almost linearly as a function of the diesel price. At a price of $\$ 0.50 / \mathrm{L}$, the NPC is $\$ 115,015$, which is a $10 \%$ increase in NPC for a $100 \%$ increase in diesel price. However, it may be noted that increase in diesel price can significantly reduce the emissions by altering the selection of energy supply options and shifting away from diesel to renewable energy generation. Increasing the diesel price to significantly high levels may also result in a reduction in NPC because of complete new selection of new supply options [15].

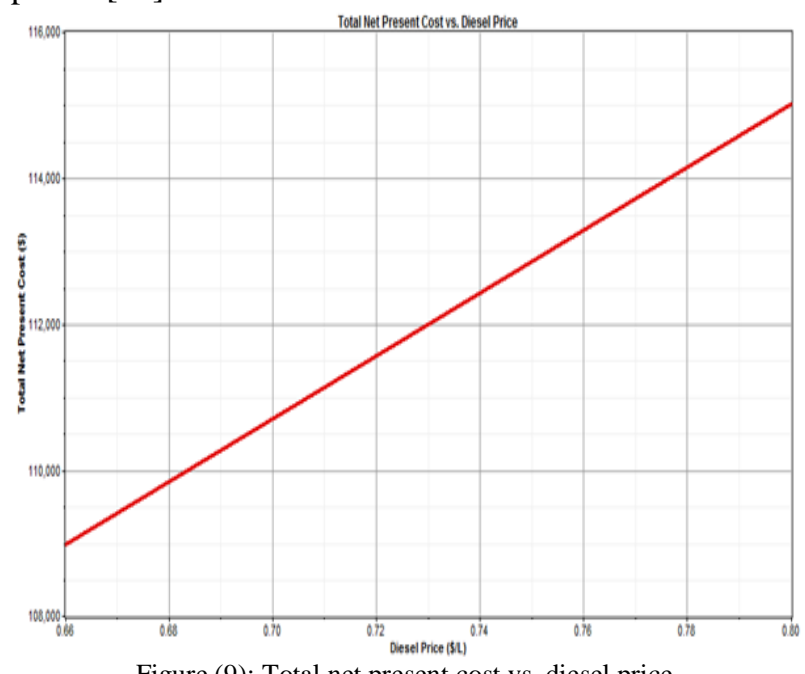

Figure (9): Total net present cost vs. diesel price 
HOMER generated a simulated option with an optimal system being one without an alternative source, which means the building load supplied electricity $100 \%$ from the grid as shown in Figure (10).

The total NPC of this grid-only method came solely from the grid since the grid was the only supply.

The output shows that a total energy of $945,350 \mathrm{kWh} /$ year was purchased from the grid and no power supply came from the PV system as illustrated in Table (1).

It can be noted there is no capital cost because no alternative system needed to be purchased or installed in this phase of the analysis.

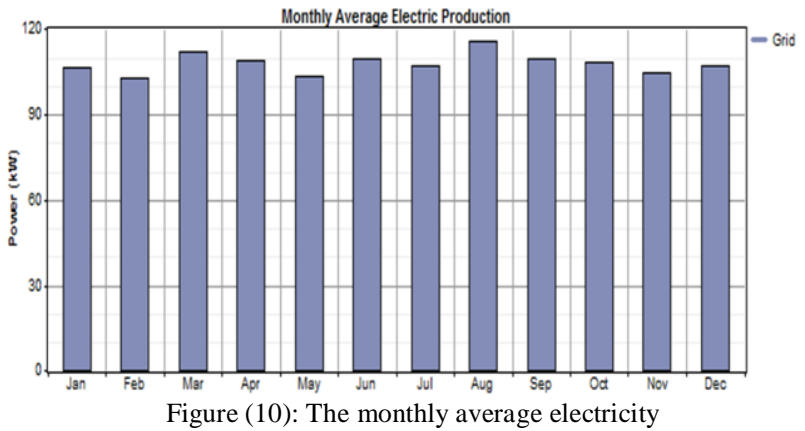

Table (1): Grid only system electricity consumption

\begin{tabular}{|l|l|l|l|}
\hline Electricity & Component & $\begin{array}{l}\text { Production } \\
\text { (KWh/yr.) }\end{array}$ & $\begin{array}{l}\text { Fraction } \\
\%\end{array}$ \\
\hline Production & $\begin{array}{l}\text { Grid } \\
\text { purchase }\end{array}$ & 945,350 & 100 \\
\hline Consumption & $\begin{array}{l}\text { AC primary } \\
\text { load }\end{array}$ & 945,349 & 100 \\
\hline
\end{tabular}

Figure (11) shows the HOMER output results ordered from lowest NPC for adding the alternative system to the simulation.

The optimal result for HOMER depending on the NPC is to use a grid-only method as the first choice. This means that any alternative system will not be considered an optimal solution.

The reason for this is the grid-only system is assumed to carry no capital or maintenance cost.

It can then be deduced that the most cost effective option is to use the supply from the grid only system without a PV generator.

This option has a total net present cost (NPC) of $\$ 845,932$ and the lowest cost of energy (COE) of $\$ 0.07 / \mathrm{kWh}$. This option also results in an operating cost of $\$ 66,175 /$ year.

The operating cost was generated by multiplying the total energy purchased by the purchase prices.

The initial capital cost in this case is zero due to the lack of a PV generator and inverter.

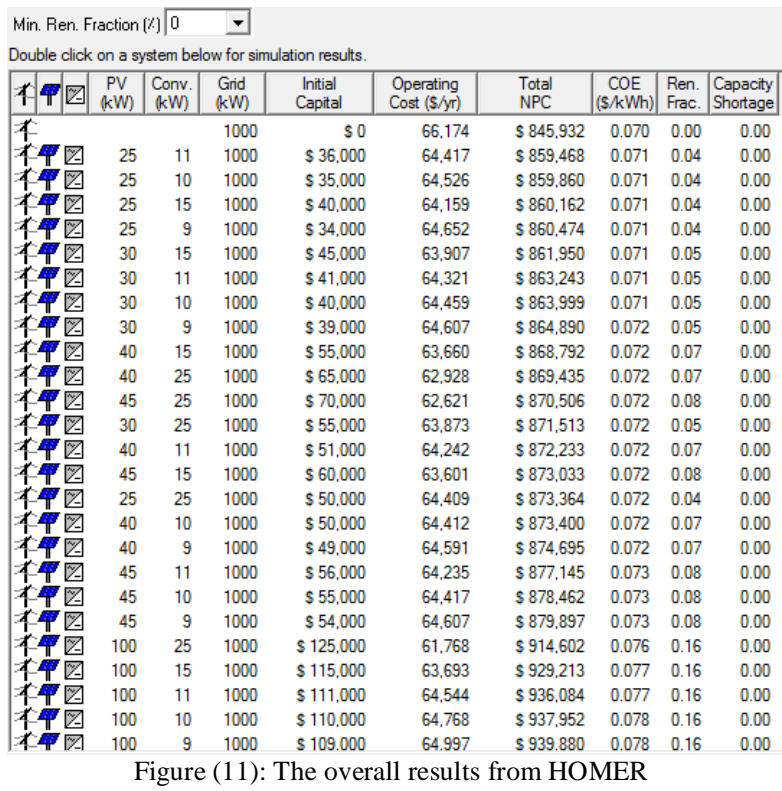

For the optimal overall result HOMER gives only two systems, as shown in Figure (12).

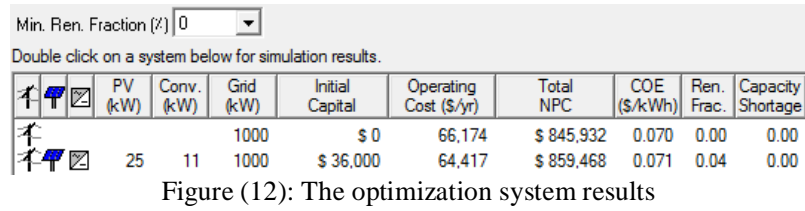

From Figure (12) there is only one optimal system with a PV system. This system has a PV fraction of $4 \%$ with a grid fraction of $96 \%$. For the optimal alternative system, the PV system and inverter size are $25,11 \mathrm{KW}$ as shown in Table (2) with a capital cost of $\$ 25,000$ and $\$ 11,000$ for the PV kit and inverter respectively. For the O\&M the PV cost was assumed to be zero while the inverter is $\$ 1,406$.

\begin{tabular}{|c|c|c|c|c|}
\hline Component & $\begin{array}{l}\text { Size } \\
(\text { KW) }\end{array}$ & $\begin{array}{l}\text { Capital } \\
\text { cost }(\$)\end{array}$ & $\begin{array}{l}\text { O\&M } \\
(\$)\end{array}$ & $\begin{array}{l}\text { Total } \\
\text { (\$) }\end{array}$ \\
\hline PV Kit & 25 & 25,000 & 0 & 28,426 \\
\hline Inverter & 11 & 11,000 & 1,406 & 16,142 \\
\hline
\end{tabular}

The alternative system with $4 \%$ fraction produces 42,109 KWh per year. On the other hand, the system purchases $910,671 \mathrm{KWh}$ per year from the grid, as shown in Table (3)

Table (3): Electrical data from the simulation

\begin{tabular}{|l|l|l|l|}
\hline Electricity & Component & $\begin{array}{l}\text { Production } \\
\text { (KWh/yr.) }\end{array}$ & $\begin{array}{l}\text { Fraction } \\
\%\end{array}$ \\
\hline Production & $\begin{array}{l}\text { Alternative } \\
\text { system }\end{array}$ & 42,109 & 4 \\
\cline { 2 - 4 } & Grid purchase & 910,671 & 96 \\
\hline Consumption & $\begin{array}{l}\text { AC primary } \\
\text { load }\end{array}$ & 945,349 & 100 \\
\cline { 2 - 4 } & Grid sale & 0 & 0 \\
\hline
\end{tabular}

For the economic analysis, Table (4) shows that the NPC for the system is $\$ 859,468$, which is higher than the NPC of the grid-only system. In addition, this increase in NPC 
makes the COE of the alternative system $(0.071 / \mathrm{KWh})$ higher than the COE for the grid-only system. The operating cost was reduced to $\$ 63,857 / \mathrm{yr}$. This reduction was possible due to the excess of the load requirements being sold back to the grid during the day (when the PV system is generating higher power due to the greater amount of radiation).

Table (4): Economic data for the system
\begin{tabular}{|l|l|}
\hline Component & Total (\$) \\
\hline PV system & 44,568 \\
\hline Grid purchase & 814,900 \\
\hline NPC & 859,468 \\
\hline COE & $0.071 / \mathrm{KWh}$ \\
\hline Operating & $63,857 / \mathrm{yr}$ \\
\hline
\end{tabular}

After the aforementioned analysis comparing the cost of the PV system with a grid only system, HOMER's optimal system was found not to be cost-effective.

One of the HOMER options used here is to force the PV system to cover any fraction of the load and give the optimization result for it. After choosing three different fractions $25 \%, 50 \%, 75 \%$ of the building load, the power consumption is considered.

\section{The First Plan}

a. Design System (1):

In the figure below HOMER shows the optimal system that covers $25 \%$ of the governmental building load. The optimal system presented required $33 \%$ coverage instead of $25 \%$ of the governmental building load as shown in Figure (13).

$$
\text { Min. Ren. Fraction (x) } 25
$$

Double click on a system below for simulation results.

\begin{tabular}{|c|c|c|c|c|c|c|c|c|}
\hline 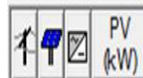 & $\begin{array}{l}\text { Conv. } \\
\text { kW) }\end{array}$ & $\begin{array}{l}\text { Gid } \\
(\mathrm{kW})\end{array}$ & $\begin{array}{l}\text { Intial } \\
\text { Captal }\end{array}$ & $\begin{array}{l}\text { Operating } \\
\operatorname{Cost}(S / y)\end{array}$ & $\begin{array}{l}\text { Total } \\
\text { NPC }\end{array}$ & $\left.\begin{array}{c}C O E \\
(\$ k W h)\end{array}\right)$ & $\begin{array}{l}\text { Ren. } \\
\text { Frac. }\end{array}$ & $\begin{array}{l}\text { Capacty } \\
\text { Shotage }\end{array}$ \\
\hline 200 & 100 & 1000 & $\$ 30000$ & 52.175 & $\$ 966,96$ & 0.080 & 0.33 & 0.00 \\
\hline
\end{tabular}

Figure (13): Plan (1), the optimal result for system (1)

With the new system the monthly average electricity production is shown in Figure (14).

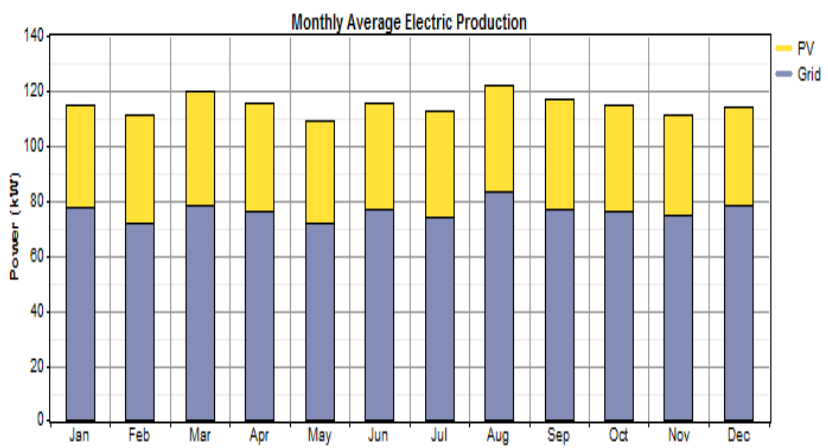

Figure (14): The monthly average electric production for system (1)

The new PV system configuration shown in Table (5) shows that the new bigger PV panel size obtained for the optimal system is the same size of the inverter. The PV size is $200 \mathrm{KW}$ with a capital cost of \$200,000while the maintenance costs are equal to zero. The inverter cost with the regular maintenance equals $\$ 12,783$.

Copyright to IJIREEICE
Table (5): Plan (1) system size and cost for system (1)

\begin{tabular}{|l|l|l|l|l|}
\hline Component & $\begin{array}{l}\text { Size } \\
(\mathbf{K W})\end{array}$ & $\begin{array}{l}\text { Capital } \\
\text { cost } \mathbf{( \$ )}\end{array}$ & $\begin{array}{l}\text { O\&M } \\
\mathbf{( \$ )}\end{array}$ & $\begin{array}{l}\text { Total } \\
\mathbf{( \$ )}\end{array}$ \\
\hline PV Kit & 200 & 200,000 & 0 & 227,411 \\
\hline Inverter & 100 & 100,000 & 12,783 & 146,743 \\
\hline
\end{tabular}

Table (6) shows the details of the electrical production and consumption. The $33 \%$ of the building load supplied by the alternative system produced $336,872 \mathrm{KWh} / \mathrm{yr}$ while the rest of the load $(67 \%)$ supplied by the grid produced $669,045 \mathrm{KWh} / \mathrm{yr}$.

In this option, the system still gets most of the power from the grid. In addition the system sellback is $6,560 \mathrm{KWh} / \mathrm{yr}$ to the grid.

Table (6): Plan (1) Electrical detail for system (1)

\begin{tabular}{|l|l|l|l|}
\hline Electricity & Component & $\begin{array}{l}\text { Production } \\
\text { (KWh/yr.) }\end{array}$ & $\begin{array}{l}\text { Fraction } \\
\text { \% }\end{array}$ \\
\hline Production & $\begin{array}{l}\text { Alternative } \\
\text { system }\end{array}$ & 336,872 & 33 \\
\cline { 2 - 4 } & $\begin{array}{l}\text { Grid } \\
\text { purchase }\end{array}$ & 669,045 & 67 \\
\hline Consumption & $\begin{array}{l}\text { AC primary } \\
\text { load }\end{array}$ & 945,349 & 99 \\
\cline { 2 - 4 } & Grid sale & 6,560 & 1 \\
\hline
\end{tabular}

The cost of the alternative system is $\$ 374,154$. The NPC, COE and operating cost of the new system are $\$ 966,969$, $0.08 / \mathrm{KWh}$ and $52,157 / \mathrm{yr}$ respectively.

Most of the power is still purchased from the grid $(\$ 592,815)$ Table $(7)$.

Table (7): Plan (1) Economic analysis for system (1)

\begin{tabular}{|l|l|}
\hline Component & Total (\$) \\
\hline PV system & 374,154 \\
\hline Grid purchase & 592,815 \\
\hline NPC & 966,969 \\
\hline COE & $0.08 / \mathrm{KWh}$ \\
\hline Operating & $52,157 / \mathrm{yr}$. \\
\hline
\end{tabular}

b. Design System (2):

In Figure (15) below HOMER shows the optimal system for a new fraction. The PV System size increased to 350 $\mathrm{KW}$ while the inverter size increased to $150 \mathrm{KW}$.

\section{Min. Ren. Fraction $(x) \sqrt{50} \square$ \\ Double cick on a system below for simudition results.

\begin{tabular}{|c|c|c|c|c|c|c|c|c|}
\hline $1 甲 \mathrm{Q}_{\mathrm{kW}}^{\mathrm{PV}}$ & $\begin{array}{l}\text { Conv. } \\
\text { kW }\end{array}$ & $\begin{array}{l}\text { Gid } \\
\mathrm{kW}\end{array}$ & $\begin{array}{l}\text { Intial } \\
\text { Captal }\end{array}$ & $\begin{array}{l}\text { Operding } \\
\operatorname{Cost}(S / x)\end{array}$ & $\begin{array}{l}\text { Total } \\
\mathrm{NPC}\end{array}$ & $\begin{array}{c}\text { COE } \\
(S / k W h)\end{array}$ & $\begin{array}{l}\text { Ren. } \\
\text { Frac. }\end{array}$ & $\begin{array}{l}\text { Capacty } \\
\text { Shotagoe }\end{array}$ \\
\hline ( & 150 & & & & & & & \\
\hline
\end{tabular}

Figure (15): Plan (1), the optimal result for system (2)

The new system covers $52 \%$ of the total building load. The optimal system is to cover $52 \%$ instated of $50 \%$ of the building load. Figure (16) shows the monthly average electrical production with system 2 . 


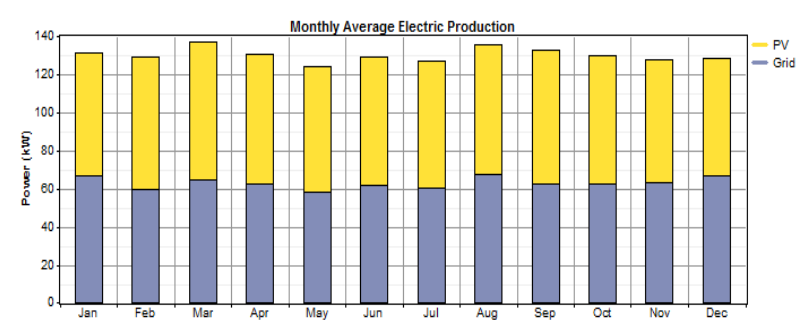

Figure (16): The monthly average of electric production for system (2)

The new PV system configuration shown in Table (8) shows that the new larger PV panel size costs $\$ 397,970$ while the new inverter total costs $\$ 220,115$.

Table (8): Plan 1 system size and cost for system (2)

\begin{tabular}{|l|l|l|l|l|}
\hline Component & $\begin{array}{c}\text { Size } \\
\mathbf{( K W )}\end{array}$ & $\begin{array}{c}\text { Capital } \\
\text { cost } \mathbf{( \$ )}\end{array}$ & $\begin{array}{c}\text { O\&M } \\
\mathbf{( \$ )}\end{array}$ & $\begin{array}{c}\text { Total } \\
\mathbf{( \$ )}\end{array}$ \\
\hline PV Kit & 350 & 350,000 & 0 & 397,970 \\
\hline Inverter & 150 & 150,000 & 19,175 & 220,115 \\
\hline
\end{tabular}

Table (9) shows the detail of the electrical production and consumption. The alternative system supplied $52 \%$ of the building load and produced 589,526KWh/yr while the rest of the load $(48 \%)$ was supplied by the grid and produced $552,111 \mathrm{KWh} / \mathrm{yr}$. The system is starting to get a higher amount of power from the PV system than from the grid. In addition, the system sell-back was $64,865 \mathrm{KWh} / \mathrm{yr}$ to the grid.

Table (9): Plan (1) Electrical detail for system (2)

\begin{tabular}{|l|l|l|l|}
\hline Electricity & Component & $\begin{array}{l}\text { Production } \\
(\mathbf{K W h} / \mathbf{y r} .)\end{array}$ & $\begin{array}{c}\text { Fraction } \\
\text { \% }\end{array}$ \\
\hline Production & $\begin{array}{l}\text { Alternative } \\
\text { system }\end{array}$ & 589,526 & 52 \\
\cline { 2 - 4 } & $\begin{array}{l}\text { Grid } \\
\text { purchase }\end{array}$ & 552,111 & 48 \\
\hline Consumption & $\begin{array}{l}\text { AC primary } \\
\text { load }\end{array}$ & 945,349 & 94 \\
\cline { 2 - 4 } & Grid sale & 64,865 & 06 \\
\hline
\end{tabular}

The cost of the alternative system is $\$ 618,084$. The NPC, COE and operating cost of the new system are $\$ 1,054,089$, $0.087 / \mathrm{KWh}$ and $455,180 / \mathrm{yr}$ respectively. The grid purchase cost is $\$ 436,005$, as shown in Table (10).

Table (10): Plan (1) Economic data for the system (2)

\begin{tabular}{|l|l|}
\hline Component & Total (\$) \\
\hline PV system & 618,084 \\
\hline Grid purchase & 436,005 \\
\hline NPC & $1,054,089$ \\
\hline COE & $0.087 / \mathrm{KWh}$ \\
\hline Operating & $455,180 / \mathrm{yr}$ \\
\hline
\end{tabular}

c. Design System (3):

Covering $75 \%$ of the Total Load, HOMER shows the optimal system for a new fraction in Figure (17). The new $\mathrm{PV}$ system size is $850 \mathrm{KW}$ while the inverter size is $400 \mathrm{KW}$. The total net present cost is $\$ 1,353,079$.

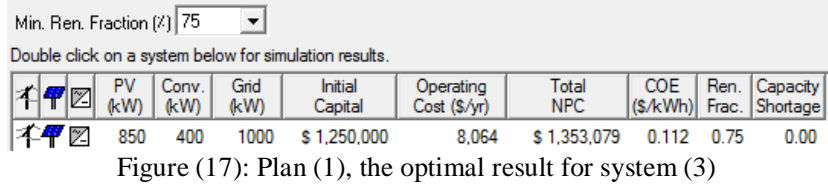

Copyright to IJIREEICE
Table (13) shows the cost of the alternative system is $\$ 1,553,470$, which makes it the highest cost variable. The NPC and the COE of the new system are $\$ 1,353,079$, $0.112 / \mathrm{KWh}$ respectively. The grid purchase and the operating cost in this system is a negative value that means the system produced more power than the required amount to cover the load and sell it to the grid.

Table (13): Plan1, Economic data for the system (3)

\begin{tabular}{|l|l|}
\hline Component & Total $\mathbf{( \$ )}$ \\
\hline PV system & $1,553,470$ \\
\hline Grid purchase & $-200,391$ \\
\hline NPC & $1,353,079$ \\
\hline COE & 0.112 \\
\hline Operating & $-149,258$ \\
\hline
\end{tabular}

\section{The Second Plan}

In the second plan we have changed the price to find a cost effective system, assuming the power utility will pay for electricity at a higher price $(\$ 0.13 / \mathrm{kwh})$ than they sell the power to the governmental buildings. 
a. Design System (1):

Table (14) shows the size and the cost of system (1) of the second plan.

Table (14): Plan (2) system (1) size and cost

\begin{tabular}{|l|l|l|l|l|}
\hline Component & $\begin{array}{l}\text { Size } \\
(\mathbf{K W})\end{array}$ & $\begin{array}{l}\text { Capital } \\
\text { cost } \mathbf{( \$ )}\end{array}$ & $\begin{array}{l}\text { O\&M } \\
\mathbf{( \$ )}\end{array}$ & $\begin{array}{l}\text { Total } \\
\mathbf{( \$ )}\end{array}$ \\
\hline PV Kit & 200 & 200,000 & 0 & 227,411 \\
\hline Inverter & 100 & 100,000 & 12,783 & 146,743 \\
\hline
\end{tabular}

In this plan's first system, 33\% of the building load is supplied by the alternative system while the rest of the load $(67 \%)$ is supplied by the grid, illustrated in Table (15). In addition, the system sells $6,560 \mathrm{KWh} / \mathrm{yr}$ to the grid.

Table (15): Plan (2) Electrical data for system (1)

\begin{tabular}{|l|l|l|l|}
\hline Electricity & Component & $\begin{array}{l}\text { Production } \\
\text { (KWh/yr.) }\end{array}$ & $\begin{array}{l}\text { Fraction } \\
\text { \% }\end{array}$ \\
\hline Production & $\begin{array}{l}\text { Alternative } \\
\text { system }\end{array}$ & 336,872 & 33 \\
\cline { 2 - 4 } & Grid purchase & 669,045 & 67 \\
\hline Consumption & $\begin{array}{l}\text { AC primary } \\
\text { load }\end{array}$ & 945,349 & 99 \\
\cline { 2 - 4 } & Grid sale & 6,560 & 1 \\
\hline
\end{tabular}

Table (16): Plan 2 Economic data for system (1)

\begin{tabular}{|l|l|}
\hline Component & Total $\mathbf{( \$ )}$ \\
\hline PV system & 374,154 \\
\hline Grid purchase & 587,783 \\
\hline NPC & 961,937 \\
\hline COE & $0.08 / \mathrm{KWh}$ \\
\hline Operating & $52,157 / \mathrm{yr}$. \\
\hline
\end{tabular}

From Table (16) the only change with the new price is the grid purchase because the price for sellback change makes the grid purchase decrease. This makes the NPC of the system decrease, thus also making the COE decrease. Finally this shows the sellback is effective economically.

\section{b. $\quad$ Design System (2):}

From Tables $(17,18)$ there is no change in the size and the cost of the optimal system. Also there is no change in the electrical consumption.

Table (17): Plan (2) system (2) size and cost

\begin{tabular}{|l|l|l|l|l|}
\hline Component & $\begin{array}{l}\text { Size } \\
(\mathbf{K W})\end{array}$ & $\begin{array}{l}\text { Capital } \\
\text { cost }(\mathbf{\$})\end{array}$ & $\begin{array}{l}\mathbf{O \& M} \\
\mathbf{( \$ )}\end{array}$ & $\begin{array}{l}\text { Total } \\
\mathbf{( \$ )}\end{array}$ \\
\hline PV Kit & 350 & 350,000 & 0 & 397,970 \\
\hline Inverter & 150 & 150,000 & 19,175 & 220,115 \\
\hline
\end{tabular}

Table (18): Plan (2) Electrical data for system (2)

\begin{tabular}{|l|c|c|c|}
\hline Electricity & Component & $\begin{array}{c}\text { Production } \\
\text { (KWh/yr.) }\end{array}$ & $\begin{array}{c}\text { Fraction } \\
\%\end{array}$ \\
\hline Production & $\begin{array}{c}\text { Alternative } \\
\text { system }\end{array}$ & 561,513 & 52 \\
\cline { 2 - 4 } & $\begin{array}{c}\text { Grid } \\
\text { purchase }\end{array}$ & 519,993 & 48 \\
\hline Consumption & $\begin{array}{c}\text { AC primary } \\
\text { load }\end{array}$ & 904,487 & 85 \\
\cline { 2 - 4 } & Grid sale & 158,33 & 15 \\
\hline
\end{tabular}

The change in the new plan took place in the economic analysis portion. The grid purchase was reduced from $\$$ 436,005 to $\$ 386,253$. Thus the NPC also decreased, which affected the $\mathrm{COE}$. The $\mathrm{COE}$ reduced from 0.087 /KWh to 0.083 /KWh, as shown in Table (19).

Table (19): Plan (2) Economic data for system (2)

\begin{tabular}{|l|l|}
\hline Component & Total $\mathbf{( \$ )}$ \\
\hline PV system & 618,084 \\
\hline Grid purchase & 386,253 \\
\hline NPC & $1,054,089$ \\
\hline COE & $0.083 / \mathrm{KWh}$ \\
\hline Operating & $31,715 / \mathrm{yr}$ \\
\hline
\end{tabular}

c. Design System (3):

Min. Ren. Fraction [i] 75 -

Double click on a system below for simulation results.

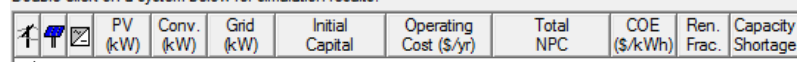

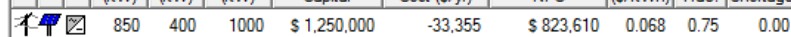
Figure (19): Plan (2), the optimal result for system (3)

For the biggest system fraction coverage of the load, the optimal system from HOMER totally changed. The new system with a different size and cost was obtained, as Shown in Figure (19). The monthly average electricity production for system 3 is shown in Figure (20).

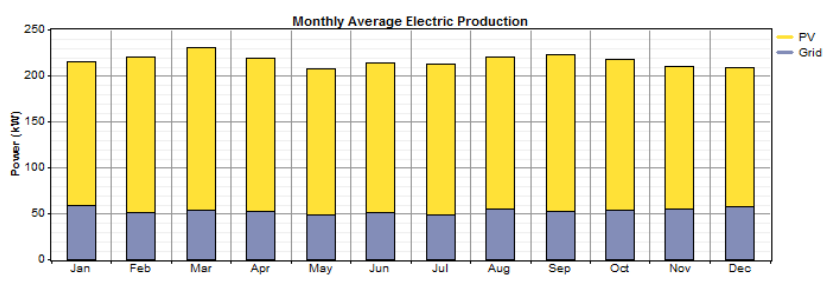

Figure (20): Plan (2) the monthly average for system (3)

For system 3, Table (20) shows PV system size and cost for the system.

Table (20): Plan (2), PV system size and cost for system (3)

\begin{tabular}{|l|l|l|l|c|}
\hline Component & \multicolumn{1}{|c|}{$\begin{array}{c}\text { Size } \\
(\mathbf{K W})\end{array}$} & $\begin{array}{c}\text { Capital } \\
\text { cost } \mathbf{( \$ )}\end{array}$ & $\begin{array}{c}\text { O\&M } \\
\mathbf{( \$ )}\end{array}$ & $\begin{array}{c}\text { Total } \\
\mathbf{( \$ )}\end{array}$ \\
\hline PV Kit & 850 & 850,000 & 0 & 966,497 \\
\hline Inverter & 400 & 400,000 & 51,133 & 586,973 \\
\hline
\end{tabular}

Table (21) shows the details of the electrical production and consumption. When $75 \%$ of the building load was supplied by the alternative system, the system produced $1,431,704 \mathrm{KWh} / \mathrm{yr}$ while the rest of the load $(25 \%)$ supplied by the grid produced $466,369 \mathrm{KWh} / \mathrm{yr}$. The system can cover the load but the electricity needed to operate during the evening and night still comes from the grid. In addition, the system sellback fractions increased to $42 \%$ and sold $690,311 \mathrm{KWh} / \mathrm{yr}$ to the grid.

\begin{tabular}{|l|l|l|c|}
\hline \multicolumn{2}{|c|}{ Table (21): Plan (2), Electrical data for system (3) } \\
\hline Electricity & Component & $\begin{array}{c}\text { Production } \\
(\mathbf{K W h} / \mathbf{y r} .)\end{array}$ & $\begin{array}{c}\text { Fraction } \\
\%\end{array}$ \\
\hline Production & $\begin{array}{l}\text { Alternative } \\
\text { system }\end{array}$ & $1,431,704$ & 75 \\
\cline { 2 - 4 } & $\begin{array}{l}\text { Grid } \\
\text { purchase }\end{array}$ & 466,369 & 25 \\
\hline Consumption & $\begin{array}{l}\text { AC primary } \\
\text { load }\end{array}$ & 945,349 & 58 \\
\cline { 2 - 4 } & Grid sale & 690,311 & 42 \\
\hline
\end{tabular}


Table (22) shows the cost of the alternative system is $\$$ and the fact that the grid system is the only system with a $1,553,470$. On the other hand, the NPC and the COE of the lower COE. In addition, the assumed sellback price is not new system are $\$ 823,610,0.068 / \mathrm{KWh}$ respectively. This acceptable because even the system selling the most power is less than in system 3 in the first plan 1 , and is due to the fact that the grid purchase increased to $\$-729,861$ when the price changed in the second plan.

Table (22): Plan (2), Economic results for system (3)
\begin{tabular}{|l|l|}
\hline Component & Total $(\$)$ \\
\hline PV system & $1,553,470$ \\
\hline Grid purchase & $-729,861$ \\
\hline NPC & 823,610 \\
\hline COE & 0.068 \\
\hline Operating & $-678,728$ \\
\hline
\end{tabular}

\section{Effect of Temperature}

It is critical to understand the negative effect on the performance of photovoltaic systems when the panels heat up due to the absorption of solar heat. This is not simply for locations with high ambient temperature. Even in mild climates, there can be degradation due to the heating of the panels. HOMER has the ability to simulate the temperature effects on a PV panel if the pertinent information is available, as seen in Figure (21). This is the temperature coefficient of power $\left(\% /{ }^{0} \mathrm{C}\right)$, the nominal operating cell temperature (NOTC, ${ }^{0} \mathrm{C}$ ), and the efficiency at standard test conditions (\%). Often these details are listed on or can be derived from the technical data sheets of the PV panel being evaluated [16].

\section{Consider effect of temperature \\ Temperature coeff. of power $\left(\% /{ }^{\circ} \mathrm{C}\right)$

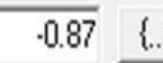 \\ Nominal operating cell temp. $\left({ }^{\circ} \mathrm{C}\right]$ \\ Efficiency at std. test conditions $(\%)$

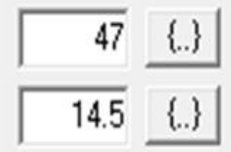

Figure (21): HOMER temperature effects inputs of Qena Al-Gadida

Both the NOTC and efficiency at standard test conditions are listed. They are $47^{\circ}$ and $14.5 \%$, respectively. The temperature coefficient of power is not listed and must be derived. Most often, technical data sheets will not list the temperature coefficient in terms of power. Instead, the temperature coefficients of the open-circuit voltage and the short-circuit current will be listed. To achieve a reasonably accurate temperature coefficient of power, equation (1) should be used [16]:

$$
\propto_{\mathrm{v}_{\mathrm{oc}}} \times \mathrm{I}_{\mathrm{mpp}}=\propto_{\mathrm{p}} \quad \text { Eqn.1 }
$$

In this equation, $\propto_{v_{o c}}$ refers to the temperature coefficient of the open circuit voltage, $I_{m p p}$ the maximum power current, and $\propto_{p}$ is the temperature coefficient of power. The resulting equation (2) is:

$$
-0.11 \mathrm{~V} /{ }^{\circ} \mathrm{C} \times 7.91 \mathrm{~A}=-0.87 \mathrm{~W} /{ }^{\circ} \mathrm{C} \quad \text { Eqn.2 }
$$

\section{IV.CONCLUSIONS}

Comparing all systems to the grid-only system was not cost effective. All the systems of the first plan have a higher NPC because of the initial cost for the PV system to the grid was still economically not acceptable. The NPC increases with the increasing size of the alternative system because the capital cost increases. The cost of energy also changes with the alternative system change. All the simulation results NPC and COE are higher than the only grid system. On the other hand, system 3 is the only system that benefits by the end of the year (because it sells to grid a larger amount of power than it purchases from the grid). The simulation for the second plan shows the same optimization results for the PV system 1 and system 2 in the electricity consumption but with a change in the NPC and the COE because of the new price. On the other hand, System 3 has the best optimization results with the lowest $\mathrm{COE}$ less than the $\mathrm{COE}$ on the grid only, and a reduction in power purchased to $21 \%$ but with high NPC.

The summary tables for the results from HOMER for the first and the second plans are shown in Tables $(23,24)$

Table (23): Plan (1), the summary table for plan (1)

\begin{tabular}{|l|l|l|l|}
\hline $\begin{array}{l}\text { Load cover } \\
\text { by PV }\end{array}$ & $25 \%$ & $50 \%$ & $75 \%$ \\
\hline Homer \% & $33 \%$ & $52 \%$ & $75 \%$ \\
\hline $\begin{array}{l}\text { PV size / } \\
\text { inverter size }\end{array}$ & $200 / 100$ & $350 / 150$ & $850 / 400$ \\
\hline COE & 0.08 & 0.087 & 0.112 \\
\hline NPC & 966,969 & $1,054,089$ & $1,353,079$ \\
\hline
\end{tabular}

Table (24): summary results for the second plan

\begin{tabular}{|l|l|l|l|}
\hline $\begin{array}{l}\text { PV \% cover } \\
\text { from the load }\end{array}$ & $25 \%$ & $50 \%$ & $75 \%$ \\
\hline $\begin{array}{l}\text { PV/ inverter } \\
\text { size }\end{array}$ & $200 / 100$ & $350 / 150$ & $850 / 400$ \\
\hline NPC & 961,938 & $1,054,089$ & 823,610 \\
\hline COE & 0.08 & 0.083 & 0.068 \\
\hline $\begin{array}{l}\text { Electricity } \\
\text { From the grid } \\
\text { (kwh/year) }\end{array}$ & 669,045 & 519,993 & 466,369 \\
\hline $\begin{array}{l}\text { Electricity Sale } \\
\text { to the grid } \\
\text { (kwh/year) }\end{array}$ & 6,560 & 158,33 & 690,311 \\
\hline
\end{tabular}

\section{REFERENCES}

[1] Renewable energy in Egypt: hydro, solar and wind, January 2013.

[2] Twaha, S.; Al-Hamouz, Z.; Mukhtiar, M.U., "Optimal hybrid renewable-based distributed generation system with feed-in tariffs and ranking technique," Power Engineering and Optimization Conference (PEOCO), 2014 IEEE 8th International , vol., no., pp.115,120, 24-25 March 2014.

[3] Roy, B.; Basu, A.K.; Paul, S., "Analysis of a grid connected PV household system in West Bengal using HOMER," Control, Instrumentation, Energy and Communication (CIEC), 2014 International Conference on , vol., no., pp.286,290, Jan. 312014 Feb. 2 2014, doi: 10.1109/CIEC.2014.6959095.

[4] Charan, V., "Feasibility analysis design of a PV grid connected system for a rural electrification in Ba, Fiji," Renewable Energy Research and Application (ICRERA), 2014 International Conference on , vol., no., pp.61,68, 19-22 Oct. 2014, doi: 10.1109/ICRERA.2014.7016467.

[5] Roy, B.; Basu, A.K.; Paul, S., "Techno-economic feasibility analysis of a grid connected solar photovoltaic power system for a residential load," Automation, Control, Energy and Systems (ACES), 2014 First International Conference on , vol., no., pp.1,5, 1-2 Feb. 2014, doi: 10.1109/ACES.2014.6808005. 
[6] Mazumder, P.; Jamil, M.H.; Das, C.K.; Matin, M.A., "Hybrid energy optimization: An ultimate solution to the power crisis of St. Martin Island, Bangladesh," Strategic Technology (IFOST), 2014 9th International Forum on, vol., no., pp.363,368, 21-23 Oct. 2014, doi: 10.1109/IFOST.2014.6991141.

[7] Makbul A.M. Ramli, Ayong Hiendro, Khaled Sedraoui, Ssennoga Twaha, Optimal sizing of grid-connected photovoltaic energy system in Saudi Arabia, Renewable Energy, Volume 75, March 2015, Pages 489-495, ISSN 0960-1481, http://dx.doi.org/10.1016/j.renene.2014.10.028. (http://w ww. Scien cedire ct.com/science/articl e/pii/S09601 48114006557).

[8] Mohammed, O .H.; Amirat, Y.; Benbouzid, M.; Elbaset, A.A., "Optimal design of a PV/fuel cell hybrid power system for the city of Brest in France," Green Energy, 2014 International Conference on , vol., no., pp.119,123, 25-27 March 2014, doi: 10.1109/ICGE.2014.6835408.

[9] Mukhtaruddin, R.N.S.R.; Rahman, H.A.; Hassan, M.Y., "Economic analysis of grid-connected hybrid photovoltaic-wind system in Malaysia," Clean Electrical Power (ICCEP), 2013 International Conference on , vol., no., pp.577,583, 11-13 June 2013, doi: 10.1109/ICCEP.2013.6586912.

[10] Hybrid Optimization Model for electric Renewable Energy (HOMER), http://www.homerenergy.com.

[11] Ministry of Electricity \& Energy, Egypt Electricity Company, Consumption Rates Report.

[12] National Renewable Energy Laboratory (NREL ) Available at www.nrel.gov.

[13] Egyptian Electric Utility for Consumer Protection and Regulatory Agency, Renewable Energy - Feed-in Tariff Projects' Regulations.

[14] NASA Surface Meteorology and Solar Energy [Online]. Available at http://www.nasa.gov.

[15] Omar Hafez, "Some Aspects of Microgrid Planning and Optimal Distribution Operation in the Presence of Electric Vehicles", the University of Waterloo, MSc, Waterloo, Ontario, Canada, 2011.

[16] Brandon H. Newell, "THE EVALUATION OF HOMER AS A MARINE CORPS EXPEDITIONARY ENERGY PREDEPLOYMENT TOOL", MSc, September 2010, NAVAL POSTGRADUATE SCHOOL, MONTEREY, CALIFORNIA.

\section{BIOGRAPHIES}

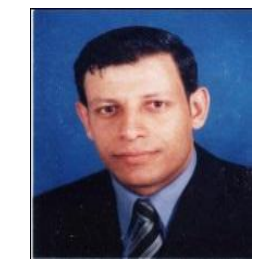

Ibrahim A. Nassar was born 1976 in El-Beheria, Egypt. He received the B.Sc. and M.Sc. degrees in electrical engineering from Al Azhar University, Egypt in 1999 and 2004, respectively. He obtained his Ph.D. degree from University of Rostock, Germany in 2011 .

Currently he is a lecturer at Electrical Power and Machine Department, Faculty of Engineering, Alazhar University, Cairo, Egypt

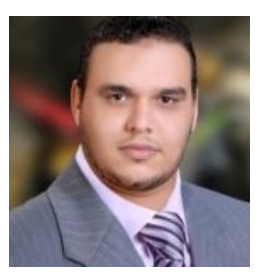

Abdelrahman Atallah Z. Saleh was born in Nag Hamadi, Qena, Egypt, in 1989. He received the B.Sc. in Electrical Engineering from the University of Benha, Benha, Egypt, in 2012. After graduation he joined The Integrated Technical Educational Cluster, Cabient of Minister, from 2012 to 2014. In May 2014 he joined The New Urban Communities Authority (NUCA). He is currently working toward the M.Sc. degree on Simulations of Renewable Energy Systems at the university of Al-Azhar. His research interests are in the area of renewable energy systems, computer applications. 